\title{
Reasearch on Entrepreneurship and Career Planning of Students in Network Engineering
}

\author{
Guibao Liu ${ }^{1}$, Min Xü ${ }^{2}$ \\ ${ }^{1}$ College of Psychology and Education, Zaozhuang University, Zaozhuang, Shandong, 277100, China \\ ${ }^{2}$ College of Information Engineering, Zaozhuang University, Zaozhuang, Shandong, 277100, China
}

Keywords: Network engineering, Career planning, Employment.

\begin{abstract}
Network engineering is an emerging major in China, and its graduate have good employment situation. In order to keep this state, we research the career planning to this major. This research aimed to explore the cognition and behavior of college students of network engineering major in the career planning. Through questionnaire survey, we have mastered the reason for students to choose the major, their understanding to the future work, the cognitive level of themselves, the goals and action to goals, and the attitude towards career planning course.
\end{abstract}

\section{Introduction}

In China, Higher education has entered the stage of mass education from the elite education. In 2014 , there are 7,270,000 university graduates, in 2015, the number is expected to reach 7,500,000, increasing about 200,000 per year. Coupled with the contradiction between supply and demand structural contradictions and other reasons, College Students' employment is very difficult. The network engineering major aims to adapt to the rapid development of information technology, it is a new major to most universities of China. According to the survey of graduates, most graduates of network engineering are engaged in the work related to this major. How should we help the students in the career planning, in order to maintain the good momentum of this major? Taking the students of network engineering of Zaozhuang University as the object, we made a survey of career planning.

\section{The status of the students' career planning of network engineering}

In order to investigate the cognitive and behavioral status of the students of network engineering, a questionnaire about university students' career planning of network engineering was designed. Then through random sampling, the choice was 80 students, a total of 80 questionnaires were distributed, 78 valid questionnaires were returned, the effective rate was $97 \%$, the specific conditions of the subjects are shown in table 1.

Table 1. Specific conditions of the subjects

\begin{tabular}{|c|c|c|c|}
\hline Item & Category & Number & Percent(\%) \\
\hline \multirow{3}{*}{ Grade } & Freshman & 30 & $38 \%$ \\
\cline { 2 - 4 } & Sophomore & 23 & $30 \%$ \\
\cline { 2 - 4 } & Junior & 25 & $32 \%$ \\
\hline \multirow{2}{*}{ Gender } & Male & 47 & $60 \%$ \\
\cline { 2 - 4 } & Female & 31 & $40 \%$ \\
\hline \multirow{2}{*}{ Family } & City & 32 & $41 \%$ \\
\cline { 2 - 4 } & Country & 46 & $59 \%$ \\
\hline \multirow{2}{*}{$\begin{array}{c}\text { Student } \\
\text { Cadres }\end{array}$} & Yes & 30 & $38 \%$ \\
\cline { 2 - 4 } & No & 48 & $62 \%$ \\
\hline
\end{tabular}




\subsection{The selection basis and satisfaction of network engineering major}

Table 2. Basis for selecting the network engineering major

\begin{tabular}{|c|c|c|c|c|c|c|c|c|}
\hline \multirow{2}{*}{ Item } & \multicolumn{2}{|c|}{ Personal interest } & \multicolumn{2}{c|}{ Others suggest } & \multicolumn{2}{c|}{ Career prospects } & \multicolumn{2}{c|}{$\begin{array}{c}\text { Randomly } \\
\text { chosen }\end{array}$} \\
\cline { 2 - 9 } & $\mathrm{n}$ & $\%$ & $\mathrm{n}$ & $\%$ & $\mathrm{n}$ & $\%$ & $\mathrm{n}$ & $\%$ \\
\hline Freshman & 7 & $23 \%$ & 16 & $53 \%$ & 7 & $23 \%$ & 0 & $0 \%$ \\
\hline Sophomore & 1 & $4 \%$ & 12 & $52 \%$ & 10 & $44 \%$ & 0 & $0 \%$ \\
\hline Junior & 11 & $44 \%$ & 6 & $24 \%$ & 6 & $24 \%$ & 2 & $8 \%$ \\
\hline Summary & 19 & $24 \%$ & 34 & $44 \%$ & 23 & $29 \%$ & 2 & $3 \%$ \\
\hline
\end{tabular}

Students choose this major most according to the suggest of others, it is even more than $50 \%$ in freshman and t Sophomore. Thus, the majority of college students apply for this major was others sugest, such as parents, teachers, and so on, rather than their own interests. But through three years of study, most students have a certain interest in the major.

Although the choice of this major is to follow the suggest of others, but the satisfaction of students to this major is very high,which can be seen in the table 3.

Table 3. Satisfaction in network engineering

\begin{tabular}{|c|c|c|c|c|c|c|c|c|c|c|}
\hline \multirow{2}{*}{ Item } & \multicolumn{2}{|c|}{$\begin{array}{c}\text { Very } \\
\text { satisfied }\end{array}$} & \multicolumn{2}{c|}{ satisfied } & \multicolumn{2}{c|}{$\begin{array}{c}\text { General } \\
\text { degree }\end{array}$} & \multicolumn{2}{c|}{ Dissatisfied } & \multicolumn{2}{c|}{$\begin{array}{c}\text { far from } \\
\text { gruntled }\end{array}$} \\
\cline { 2 - 12 } & $\mathrm{n}$ & $\%$ & $\mathrm{n}$ & $\%$ & $\mathrm{n}$ & $\%$ & $\mathrm{n}$ & $\%$ & $\mathrm{n}$ & $\%$ \\
\hline Freshman & 3 & $10 \%$ & 16 & $53 \%$ & 10 & $33 \%$ & 1 & $3 \%$ & 0 & $0 \%$ \\
\hline Sophomore & 2 & $9 \%$ & 10 & $43 \%$ & 8 & $35 \%$ & 2 & $9 \%$ & 1 & $4 \%$ \\
\hline Junior & 5 & $20 \%$ & 13 & $52 \%$ & 7 & $28 \%$ & 0 & $0 \%$ & 0 & $0 \%$ \\
\hline Summary & 10 & $13 \%$ & 39 & $50 \%$ & 25 & $32 \%$ & 3 & $4 \%$ & 1 & $1 \%$ \\
\hline
\end{tabular}

\subsection{The cognitive status of the career planning in network engineering}

From the table $4,56 \%$ of college students believe that career planning is important, the degree of attention from high to low is Freshman, Junior, Sophomore.

Zaozhuang University set up career planning courses in the second term of first grade to network engineering major, freshman students have just concluded this course, junior students will be employed at once, As a result, they think career planning is very important. The reasons of $48 \%$ sophomore students think it is no matter of career planning will be researched in the future. We need to strengthen the education of career planning, which is conducive to their better development and career.

Table 4. The cognitive status of the scareer planning in network engineering

\begin{tabular}{|c|c|c|c|c|c|c|c|c|c|c|}
\hline \multirow{2}{*}{ Item } & \multicolumn{2}{|c|}{ Very important } & \multicolumn{2}{|c|}{ Important } & \multicolumn{2}{|c|}{ No mater } & \multicolumn{2}{c|}{ Not important } & \multicolumn{2}{|c|}{$\begin{array}{c}\text { Far from } \\
\text { important }\end{array}$} \\
\cline { 2 - 12 } & $\mathrm{n}$ & $\%$ & $\mathrm{n}$ & $\%$ & $\mathrm{n}$ & $\%$ & $\mathrm{n}$ & $\%$ & $\mathrm{n}$ & $\%$ \\
\hline Freshman & 9 & $30 \%$ & 21 & $70 \%$ & 0 & $0 \%$ & 0 & $0 \%$ & 0 & $0 \%$ \\
\hline Sophomore & 7 & $30 \%$ & 5 & $22 \%$ & 11 & $48 \%$ & 0 & $0 \%$ & 0 & $0 \%$ \\
\hline Junior & 6 & $24 \%$ & 18 & $72 \%$ & 1 & $4 \%$ & 0 & $0 \%$ & 0 & $0 \%$ \\
\hline Summary & 22 & $28 \%$ & 44 & $56 \%$ & 12 & $15 \%$ & 0 & $0 \%$ & 0 & $0 \%$ \\
\hline
\end{tabular}

Network engineering students think they know themselves, in the self, interest, personality, values and ability of these aspects, as shown in table 5. 
Table 5. The self-perception of network engineering students

\begin{tabular}{|c|c|c|c|c|c|}
\hline \multirow{3}{*}{ Grade } & Item & $\begin{array}{c}\text { Clearly } \\
\text { understanding }\end{array}$ & Understanding & Unclear & $\begin{array}{c}\text { Not } \\
\text { understanding }\end{array}$ \\
\hline \multirow{4}{*}{ Freshman } & Self & $10 \%$ & $83 \%$ & $7 \%$ & $0 \%$ \\
\cline { 2 - 6 } & Interest & $23 \%$ & $63 \%$ & $13 \%$ & $0 \%$ \\
\cline { 2 - 6 } & Character & $17 \%$ & $77 \%$ & $7 \%$ & $0 \%$ \\
\cline { 2 - 6 } & Sense of worth & $23 \%$ & $67 \%$ & $10 \%$ & $0 \%$ \\
\cline { 2 - 6 } & Ability & $13 \%$ & $70 \%$ & $17 \%$ & $0 \%$ \\
\hline \multirow{4}{*}{ Sophomore } & Self & $26 \%$ & $39 \%$ & $22 \%$ & $13 \%$ \\
\cline { 2 - 6 } & Interest & $22 \%$ & $48 \%$ & $30 \%$ & $0 \%$ \\
\cline { 2 - 6 } & Character & $17 \%$ & $57 \%$ & $13 \%$ & $13 \%$ \\
\cline { 2 - 6 } & Sense of worth & $30 \%$ & $39 \%$ & $26 \%$ & $4 \%$ \\
\cline { 2 - 6 } & Ability & $22 \%$ & $57 \%$ & $17 \%$ & $4 \%$ \\
\cline { 2 - 6 } & Self & $36 \%$ & $44 \%$ & $20 \%$ & $0 \%$ \\
\cline { 2 - 6 } & Interest & $40 \%$ & $44 \%$ & $16 \%$ & $0 \%$ \\
\cline { 2 - 6 } & Character & $32 \%$ & $60 \%$ & $8 \%$ & $0 \%$ \\
\cline { 2 - 6 } & Sens of worth & $32 \%$ & $52 \%$ & $16 \%$ & $0 \%$ \\
\hline \multirow{5}{*}{ Summary } & Ability & $40 \%$ & $52 \%$ & $8 \%$ & $0 \%$ \\
\cline { 2 - 6 } & Self & $23 \%$ & $62 \%$ & $12 \%$ & $3 \%$ \\
\cline { 2 - 6 } & Interest & $28 \%$ & $53 \%$ & $19 \%$ & $0 \%$ \\
\cline { 2 - 6 } & Character & $22 \%$ & $65 \%$ & $9 \%$ & $4 \%$ \\
\cline { 2 - 6 } & Sense of worth & $28 \%$ & $54 \%$ & $17 \%$ & $1 \%$ \\
\hline
\end{tabular}

Most students know themselves clearly, understand their own interests, their own advantages and disadvantages, which is very favorable of major learning, career and life development in the future. But it is significantly lower for sophomore students in these five aspects than the freshman and junior students, which is the same. With their realize of career planning.

Thus, the network engineering students have realized the importance of career planning, and have a clear understanding of the five aspects of self-exploration. Survey shows that most of the students think that the main purpose of career planning is to determine the goals of the future struggle (54\%), the completion of the task assigned by the teacher (24\%), to find their own work (21\%).

\subsection{The behavior of career planning in network engineering}

\subsubsection{Cognition of network engineering students to employment situation}

$41 \%$ of the students think that the employment situation is generally,31\% think it is serious. Specific to different grades,41\% of the freshman think that the employment situation is generally,31\% think it is serious; $20 \%$ of the junior is generally, $40 \%$ is serious. Freshman students is more optimistic in the employment situation. While the junior students will enter the community right now, they can feel the pressure of employment, most of them think it is difficult to find a job, and more difficult to find a good job. Survey shows that $65 \%$ of the students believe that the difficult of employment is caused by the balance between supply and demand ,64\% think it is caused by the lack of own capacity, 39\% believe this because the lack of career planning or employment guidance of the relevant knowledge, 26\% blame it to expansion. Of university. All the above can be seen in table 6 .

Table 6. Cognition of network engineering students to employment situation

\begin{tabular}{|c|c|c|c|c|c|c|c|c|}
\hline \multirow{2}{*}{ Item } & \multicolumn{2}{|c|}{ Serious } & \multicolumn{2}{c|}{ General } & \multicolumn{2}{c|}{ Unclear } & \multicolumn{2}{c|}{ Fine } \\
\cline { 2 - 9 } & $\mathrm{n}$ & $\%$ & $\mathrm{n}$ & $\%$ & $\mathrm{n}$ & $\%$ & $\mathrm{n}$ & $\%$ \\
\hline Freshman & 8 & $27 \%$ & 19 & $63 \%$ & 2 & $7 \%$ & 1 & $3 \%$ \\
\hline Sophomore & 6 & $26 \%$ & 8 & $35 \%$ & 4 & $17 \%$ & 5 & $22 \%$ \\
\hline Junior & 10 & $40 \%$ & 5 & $20 \%$ & 9 & $36 \%$ & 1 & $4 \%$ \\
\hline Summary & 24 & $31 \%$ & 32 & $41 \%$ & 15 & $19 \%$ & 7 & $9 \%$ \\
\hline
\end{tabular}




\subsubsection{The understanding of the working world of network engineering}

From the table 7, there are $47 \%$ students know the working world, and 38\% know the demand of the employing units. Seen from the grade, the freshman is optimistic to the employment. Personally, this optimism is a bit blind. The junior are not very clear to the working world and the demand of the employing units, both $44 \%$. This will affect the students' career choice and development, we must strengthen the guidance in this area to junior.

Table 7. The understanding of the working world of network engineering

\begin{tabular}{|c|c|c|c|c|c|c|c|c|c|}
\hline \multirow{3}{*}{ Grade } & \multirow{2}{*}{ Item } & \multicolumn{2}{|c|}{ Known clearly } & \multicolumn{2}{|c|}{ Known } & \multicolumn{2}{|c|}{$\begin{array}{c}\text { Not } \\
\text { clearly }\end{array}$} & \multicolumn{2}{|c|}{ Unknown } \\
\cline { 2 - 10 } & & $\mathrm{n}$ & $\%$ & $\mathrm{n}$ & $\%$ & $\mathrm{n}$ & $\%$ & $\mathrm{n}$ & $\%$ \\
\hline \multirow{3}{*}{ Freshman } & Working world & 4 & $13 \%$ & 18 & $60 \%$ & 7 & $23 \%$ & 1 & $3 \%$ \\
\cline { 2 - 10 } & $\begin{array}{c}\text { Demand of employing } \\
\text { units }\end{array}$ & 4 & $13 \%$ & 13 & $43 \%$ & 11 & $37 \%$ & 2 & $7 \%$ \\
\hline \multirow{3}{*}{ Sophomore } & Working world & 7 & $30 \%$ & 9 & $39 \%$ & 7 & $30 \%$ & 0 & $0 \%$ \\
\cline { 2 - 10 } & $\begin{array}{c}\text { Demand of employing } \\
\text { units }\end{array}$ & 6 & $26 \%$ & 9 & $39 \%$ & 7 & $30 \%$ & 1 & $4 \%$ \\
\hline \multirow{3}{*}{ Junior } & Working world & 4 & $16 \%$ & 10 & $40 \%$ & 11 & $44 \%$ & 0 & $0 \%$ \\
\cline { 2 - 10 } Summary & $\begin{array}{c}\text { Demand of employing } \\
\text { units }\end{array}$ & 5 & $20 \%$ & 8 & $32 \%$ & 11 & $44 \%$ & 1 & $4 \%$ \\
\cline { 2 - 10 } & $\begin{array}{c}\text { Demand of employing } \\
\text { units }\end{array}$ & 15 & $19 \%$ & 30 & $38 \%$ & 29 & $37 \%$ & 4 & $5 \%$ \\
\hline
\end{tabular}

\subsubsection{The understanding of professional goals of network engineering}

As shown in table 8, there are $33 \%$ students have a clear long-term and short-term goals. From the low to the high grade the percent is $23 \%, 39 \%, 40 \%$; There an $54 \%$ of the students have a clear short-term goal, but have no long-term goals ,in grade is 57\%, $48 \%$, 56\%;Only $12 \%$ students have no clearly goals and $1 \%$ have no goals, thus most of the students of network engineering have a clear goal in university.

There are $36 \%$ of the students get some action for their own goals, and insist on it. There are 51\% of the students act for their goals, but just for a while. There are 13\% have no action for their goals. Thus, most of the students act for their own goals, but give up because of some reasons. It is most obvious in sophomore, accounted for $61 \%$.Therefore,we must educate and guide the students pay action to their goals and hold on consistently and persistently, and we must pay more attention to sophomore students.

There are $59 \%$ of the students considered the career goals to determine the impact of learning during the school period, $28 \%$ of the students think that the impact is very big, only $4 \%$ of the students think that there is no influence. Therefore, we must help college students to develop a reasonable career planning as soon as possible.

Table 8. The understanding of professional goals of network engineering

\begin{tabular}{|c|c|c|c|c|c|c|c|c|}
\hline \multirow{2}{*}{ Item } & \multicolumn{2}{|c|}{ Long-term goals } & \multicolumn{2}{c|}{ Short-term goals } & \multicolumn{2}{c|}{ Unclearly goals } & \multicolumn{2}{c|}{ No goals } \\
\cline { 2 - 8 } & $\mathrm{n}$ & $\%$ & $\mathrm{n}$ & $\%$ & $\mathrm{n}$ & $\%$ & $\mathrm{n}$ & $\%$ \\
\hline Freshman & 7 & $23 \%$ & 17 & $57 \%$ & 5 & $17 \%$ & 1 & $3 \%$ \\
\hline Sophomore & 9 & $39 \%$ & 11 & $48 \%$ & 3 & $13 \%$ & 0 & $0 \%$ \\
\hline Junior & 10 & $40 \%$ & 14 & $56 \%$ & 1 & $4 \%$ & 0 & $0 \%$ \\
\hline Summary & 26 & $33 \%$ & 42 & $54 \%$ & 9 & $12 \%$ & 1 & $1 \%$ \\
\hline
\end{tabular}

\subsubsection{Status of career orientation of network engineering}

Survey shows that, when the students determine the career goals, $69 \%$ of them believe it will 
promote the study of the positive initiative, $59 \%$ are full of hope for the future, $55 \%$ struggle more clearly. It can be said that the status of career orientation promote the success in future.

The choice of job, the most important thing to student is the stability of work (64\%), freedom (47\%), income (45\%), the development of space (40\%), corporate culture (14\%).The stability and freedom of the work is still the pursuit of modern college students.

When the students choosing the most valued or career prospects, they can take into account the long-term development, more vision, in the career of personal interests as the starting point. Interest is the source of happiness, the original driving force, and it is conducive to the future development of students.

\section{Summary}

Through the investigation and research, it is indicated that the students choose the major is based on the suggestion of others, mostly. The degree of satisfaction is an important part of career planning. The students in network engineering have realized the importance of career planning. And they have a correct understanding of self-exploration too. It is lower at about all the performance parameters to the sophomore, we can called it intermediate phenomenon, and we must pay more attention to them.

Most of the students in this new specialty have a normal state of mind. They can view the employment correctly and objectively. They know something about the working world and the demand of the employment unit, but not clear. We need to strengthen the education in this area.

The most serious problem is the employment goals. Though most of the students have short-term goals and long-term goals, the action payed for the goals is insufficient. A goal is good, but it is essential to persevere. In this regard, we should reform the career planning courses, not only to plan, as there are implementation.

Establishing a perfect career planning system, and helping the students to develop a scientific career planning, can help the students improve the learning attitude, comprehensive quality, clear direction and employment ability, and realize the value of their life.

\section{References}

[1] Lanmei Ban, College student occupation career planning status and its influence factors, Chinese Health Psychology Journal, 3:60-61,2013.

[2] Honghe Li, Research on the cognition, attitude and behavior of medical students' career planning, Journal of China Medical University,11:138,2014.

[3] Jianxin He, The employment oriented training system of network engineering: application and practice, Computer Era, 4:62.2012.

[4] Jing Gu. Let the color of life (College students career development), Beijing: Higher Education Press, pp:183,2014. 